\title{
PHOTOPHASE INFLUENCE ON THE REPRODUCTIVE DIAPAUSE, SEASONAL MORPHS, AND FEEDING ACTIVITY OF Euschistus heros (FABR., 1798) (HEMIPTERA: PENTATOMIDAE)
}

\author{
MOURÃO, A. P. M. ${ }^{1}$ and PANIZZI, A. R. ${ }^{2}$ \\ ${ }^{1}$ Universidade Estadual de Londrina, Departamento de Agronomia, C.P. 6001, \\ CEP 86051-970, Londrina, PR, Brazil \\ ${ }^{2}$ Embrapa-Labex IPM, National Center for Agricultural Utilization Research, USDA/ARS, 1815 North University \\ Street, Peoria, IL 61604, USA \\ Correspondence to: Antônio Ricardo Panizzi, Embrapa-Labex IPM, National Center for Agricultural Utilization \\ Research, USDA/ARS, 1815 North University Street, Peoria, IL 61604, USA, e-mail: panizzia@ ncaur.usda.gov \\ Received September 26, 2000 - Accepted December 11, 2000 - Distributed May 31, 2002
}

(With 3 figures)

\begin{abstract}
Laboratory studies were conducted to verify the influence of photophase on diapause incidence in the Neotropical brown stink bug, Euschistus heros (Fabr., 1798), fed with soybean [Glycine max (L.)] Merrill pods. Nymphs were maintained at three different photophases: $10 \mathrm{~h}, 12 \mathrm{~h}$, and $14 \mathrm{~h}$, with constant temperature of $25 \pm 1{ }^{\circ} \mathrm{C}$ and relative humidity of $65 \pm 5 \%$. With $14 \mathrm{~h}$, aproximately $100 \%$ of the adults showed mature reproductive organs; the shoulder (spine) length was significantly greater (2.96 and $2.79 \mathrm{~mm}$ for females and males, respectively) than those of bugs maintained at the photophase of $12 \mathrm{~h}(2.60 \mathrm{~mm}$ for females and males) and $10 \mathrm{~h}(2.59$ and $2.53 \mathrm{~mm}$ for females and males). At the longer photophase (14 h), E. heros showed better reproductive performance and greater feeding activity than insects reared at $10 \mathrm{~h}$ and $12 \mathrm{~h}$; in all photophases bugs tended to reduce feeding from the $1 \mathrm{st}$ to the 6th week of life. Body color was considered an unreliable parameter to indicate diapause incidence. However, at $14 \mathrm{~h}, 60 \%$ of the insects were dark brown and $40 \%$ were reddish brown. These results indicate that $E$. heros enters reproductive diapause with photophase of 12 hours or less, showing immature reproductive organs or with intermediate development, with shoulder (spine) less developed and reduced feeding activity.
\end{abstract}

Key words: Neotropical brown stink bug, diapause, photoperiod, reproductive organs, feeding activity.

\section{RESUMO}

Influência da fotofase na diapausa reprodutiva, formas sazonais e atividade alimentar de Euschistus heros (Fabr., 1798) (Hemiptera: Pentatomidae)

A influência da fotofase na diapausa do percevejo-marrom Euschistus heros (Fabr.) alimentado com soja [Glycine $\max (\mathrm{L})$.$] Merrill foi estudada em laboratório. Os experimentos foram conduzidos sob$ três fotofases, $10 \mathrm{~h}, 12 \mathrm{~h} \mathrm{e} 14 \mathrm{~h}$, mantendo-se constantes a temperatura $\left(25 \pm 1^{\circ} \mathrm{C}\right)$ e a umidade relativa $(65 \pm 5 \%)$. Sob $14 \mathrm{~h}$, cerca de $100 \%$ dos insetos apresentaram órgãos reprodutivos maduros; os espinhos pronotais, medidos aos 10 dias de vida adulta, foram significativamente maiores $(2,96$ e $2,79 \mathrm{~mm}$ para fêmeas e machos, respectivamente) que os espinhos dos insetos mantidos sob $12 \mathrm{~h}(2,60 \mathrm{~mm}$ para fêmeas e machos) ou $10 \mathrm{~h}$ (2,59 e 2,53 mm para fêmeas e machos, respectivamente). Com a fotofase mais longa, ocorreu desempenho reprodutivo e atividade alimentar maiores do que o observado para adultos criados sob fotofase de $10 \mathrm{~h}$ ou $12 \mathrm{~h}$. Em todas as fotofases observou-se tendência de diminuição da atividade alimentar dos percevejos da $1^{a} \underline{a}$ à $6^{\underline{a}}$ semana. A coloração do corpo mostrou-se como um parâmetro não confiável para indicar a diapausa, mas, sob 14 h, cerca de $60 \%$ dos insetos apresentaram 
corpo marrom-escuro e os demais marrom-avermelhado. Esses resultados demonstram que esse percevejo entra em diapausa reprodutiva sob fotofase de 12 horas ou menos, apresentando órgãos reprodutivos imaturos ou com desenvolvimento intermediário, espinhos pronotais menos desenvolvidos e redução na atividade alimentar.

Palavras-chave: percevejo-marrom, diapausa, fotoperíodo, órgãos reprodutivos, atividade alimentar.

\section{INTRODUCTION}

The neotropical brown stink bug, Euschistus heros (Fabr., 1798), a secondary pest of the soybean [Glycine max (L.)] Merrill during the 1970s (Panizzi et al., 1977), is today the main stink bug pest of this crop. It is more abundant from the northern area of Paraná toward the central-west, soybean cultivation areas in Brazil (Panizzi \& Niva, 1994; Cividanes \& Parra, 1994).

When soybean or other legumes are not available and temperature and photoperiod decrease, $E$. heros enters in diapause, remaining on the soil underneath dead leaves, without feeding and reproducing (Panizzi \& Niva, 1994; Panizzi \& Hirose, 1995). In Central Brazil, this bug has been found in partial diapause between grasses or under dead leaves (Kishino \& Alves, 1994).

When entering in diapause, insects stop feeding and reproducing, disperse to shelters, accumulate their fat bodies, and remain in clusters (Denlinger, 1986; Koshiyama et al., 1994). When in diapause, some hemipterans will show change in color and body morphology (e.g., McPherson, 1974, 1975, 1977).

In previous reports, Mourão \& Panizzi (2000a, b) studied the diapause versus different seasonal morphs of E. heros in the field, as well as the photosensitivity of nymphal stages in induction of diapause in the laboratory. In this paper, we report the influence of different photophases on the reproductive diapause, on the stage of development of reproductive organs of females and males, and on the adult body morphs. Body coloration and feeding activity of adults, in diapause or not, were also studied.

\section{MATERIAL AND METHODS}

Two experiments were conducted in the Laboratory of Entomology of the National Soybean Research Center of Embrapa (Embrapa Soja), in Londrina, PR, from October 1997 to June 1998.

\section{Experiment 1}

$E$. heros adults were field collected on soybeans at the Field Experiment Station, and taken to the laboratory. Female and male pairs were put individually in plastic boxes $(11.0 \mathrm{~cm} \times 11.0 \mathrm{~cm} \mathrm{x}$ $3.5 \mathrm{~cm}$ ), and were fed with immature soybean pods cv. BR-16. The bugs were kept in an environmental chamber at $25 \pm 1^{\circ} \mathrm{C}, 65 \pm 5 \% \mathrm{RH}$ and $14 \mathrm{~h}$ of photoperiod. Egg masses obtained were separated in three groups to avoid maternal effect, and were put in Petri dishes $(9.0 \mathrm{~cm} \times 1.5 \mathrm{~cm})$ lined with moistened filter paper. Egg masses were kept at three different photophases: $10 \mathrm{~h}, 12 \mathrm{~h}$, and $14 \mathrm{~h}$, at a temperature of $25 \pm 1^{\circ} \mathrm{C}$ and $\mathrm{RH}$ of $65 \pm 5 \%$.

Nymphs were raised to adults in plastic boxes and fed soybean pods. At adult emergence, females and males were put as pairs in plastic boxes and fed soybean pods. On days 10, 20, and 30 of adult life, 120 females and 120 males were killed by freezing at each age, dissected, and the stage of development of the reproductive organs were ranked in one of three categories for females: immature: ovaries with no differentiation or no development, and no vitellary constriction (Fig. 1A); intermediate: ovaries with differentiation with visible chambers and vitellary constriction with oocytes (Fig. 1B); and mature: ovaries totally developed, with oocytes well-developed and yellow, present in the oviducts (Fig. 1C).

For males, the reproductive organs were classified as: immature: testes undeveloped of no more than $1 \mathrm{~mm}$ in length (Fig. 2A); and mature: testes well-developed of more than $1 \mathrm{~mm}$ in length filling most of the abdominal cavity (Fig. 2B). Several authors have classified the developmental stages of the reproductive organs of hemipterans (e.g., Kiritani, 1963; Banerjee \& Chatterjee, 1985; Koshiyama et al., 1994); we used the one proposed by Solbreck (1972), who worked with the pentatomid Lygaeus equestris (L., 1758). Ali \& Ewiess (1977) reported small differences in the male reproductive organs of the pentatomid Nezara viridula (L., 1758). 
Other recorded characteristics of E. heros adults were: length of the pronotum shoulder, using $\mathrm{n}=20$ individuals for each sex and insect age, which was measured under a stereomicroscope considering the point of junction of the pronotum to the scutellum until the far end of the pronotum spine; and body color (reddish brown or dark brown) $(n=60)$.

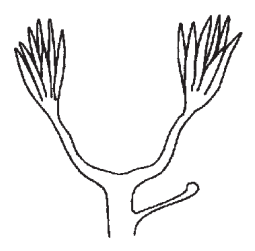

A

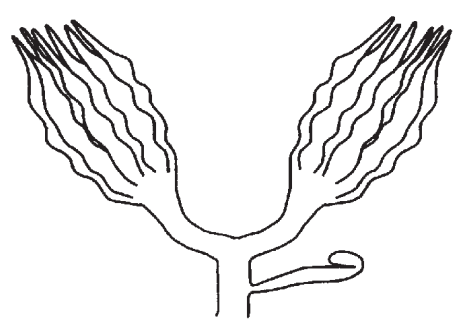

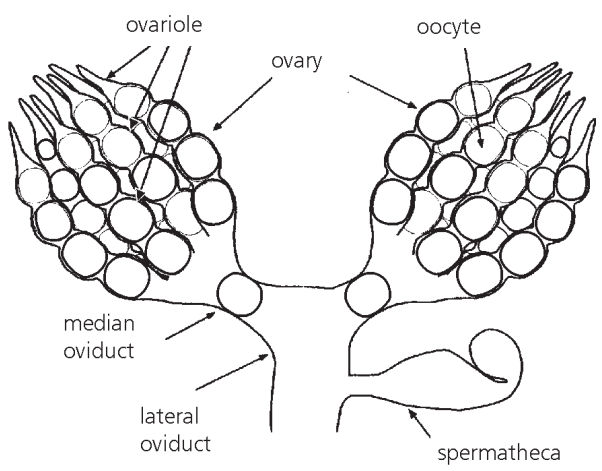

Fig. 1 - Degree of development of Euschistus heros ovary: immature (A), intermediate (B), and mature (C).

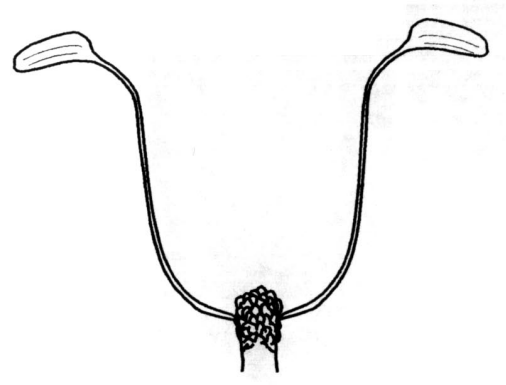

A

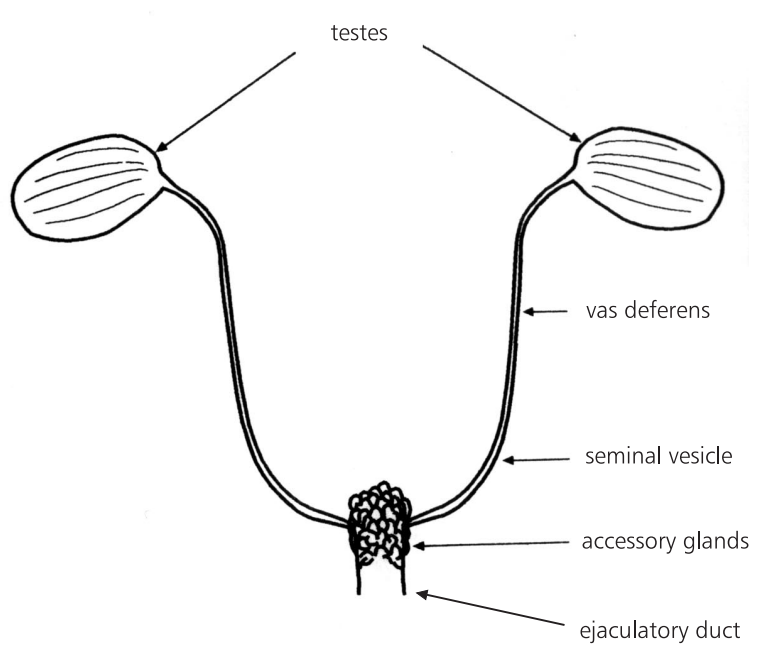

B

Fig. 2 - Degree of development of Euschistus heros testes: immature (A), and mature (B). 


\section{Experiment 2}

Egg masses of E. heros were obtained from the rearing colony maintained at Embrapa Soja. They were separated into three groups to avoid maternal effect and nymphs were reared to adulthood following the procedures described for Experiment 1 .

When nymphs reached the adult stage, each group of 15 pairs were submitted to three photophases, i.e., $10 \mathrm{~h}, 12 \mathrm{~h}$, and $14 \mathrm{~h}$, at a temperature of $25 \pm 1^{\circ} \mathrm{C}$ and $\mathrm{RH}$ of $65 \pm 5 \%$. Each pair was kept in a plastic box $(11.0 \mathrm{~cm} \times 11.0 \mathrm{~cm} \times 3.5 \mathrm{~cm})$, and was fed with immature soybean pods cv. BR-16.

Survivorship of adults and fecundity of females was monitored daily, and the feeding activity of adults recorded weekly. After 45 days of adult life, the reproductive performance of females was calculated, including percentage of females reproducing, time for first oviposition, mean number of egg masses and eggs per female, and percentage of egg hatchability.

To measure feeding activity, the bugs were allowed to feed on a soybean pod for $24 \mathrm{~h}$ each week (day 7 to day 42), and the number of flanges (or stylet sheaths) was recorded. After this feeding period, soybean pods were immersed in an acid fuchsin solution $(1 \mathrm{~g}$ of fuchsin $+10 \mathrm{ml}$ of alcohol + $500 \mathrm{ml}$ of water) for 30 minutes to stain the flanges. After this period, the pods were washed with running tap water, and the number of flanges recorded using a stereomicroscope.

Data were analyzed statistically using the SAS program (SAS Institute, 1981). Means were compared using Duncan's multiple range test, for more than one mean, and Student's $t$ test when comparing two means $(\mathrm{p} \leq 0.05)$.

\section{RESULTS AND DISCUSSION}

Degree of development of reproductive organs

The results obtained indicated that at photophases of $10 \mathrm{~h}$ and of $12 \mathrm{~h}$, both females and males, presented over $75 \%$ of individuals with immature reproductive organs. With a photophase of $14 \mathrm{~h}$, over $90 \%$ of females and $100 \%$ of males showed mature reproductive organs (Fig. 3).

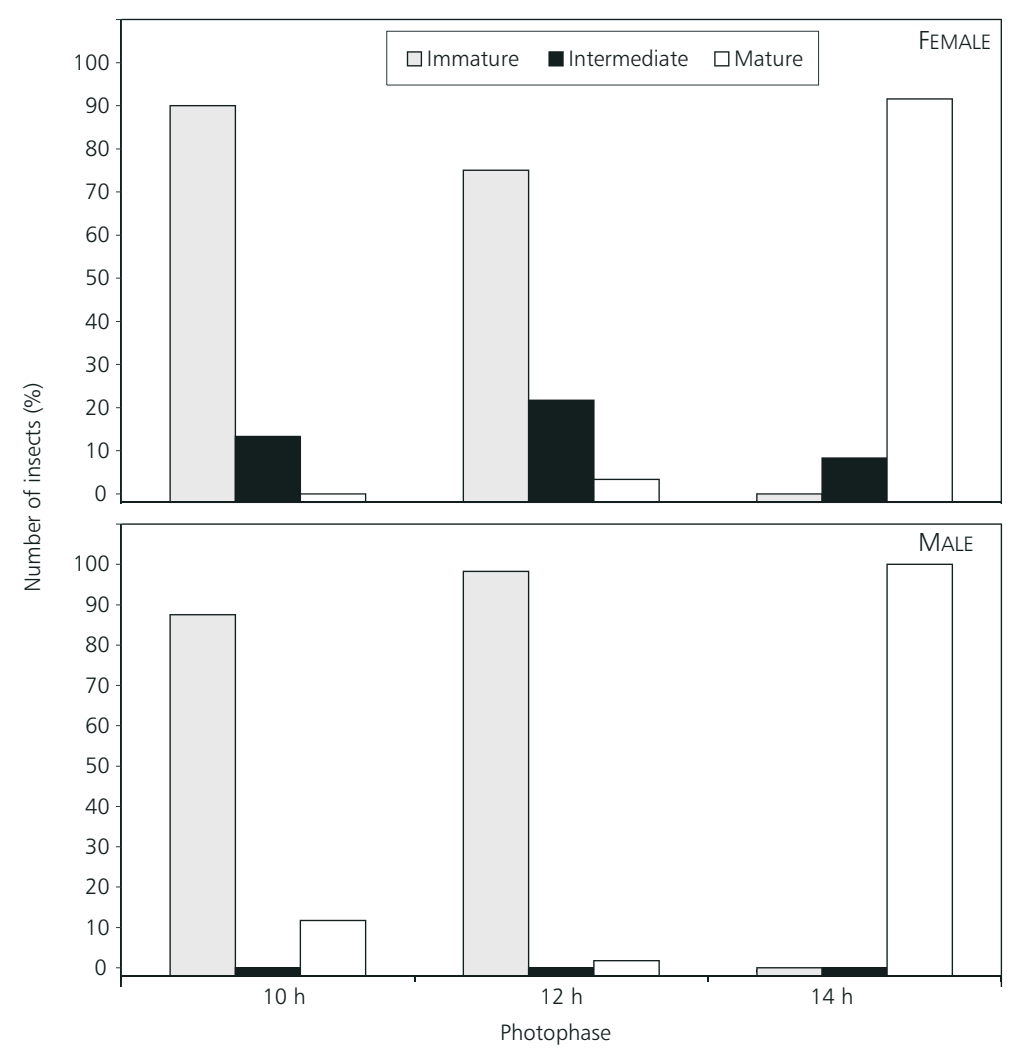

Fig. 3 - Euschistus heros with reproductive organs at different stages of development according to different photophases. 
These results are in agreement with the photophase during winter in northern Paraná (latitude $23^{\circ} 11^{\prime} \mathrm{S}$, longitude $51^{\circ} 11^{\prime} \mathrm{W}$ ) which is $10.5 \mathrm{~h}$. Similarly, the results obtained with the $14 \mathrm{~h}$ photophase, when the majority of bugs have mature reproductive organs, are in agreement with the photophase of summer (13.4 h), when bugs are reproductively active in the field. Kishino \& Alves (1994) refer to undeveloped ovaries of females E. heros in short photophases. It is known that adult diapause is characterized by development degree of the reproductive organs (e.g., Tauber et al., 1986; Kotaki \& Yagi, 1989), and a main factor driving this development is photophase (Ali \& Ewiess, 1977). Results obtained here, with E. heros showing undeveloped reproductive organs when exposed to short photophases, is also reported for other pentatomids elsewhere, such as Piezodorus hybneri (Gmelin, 1789) (Higuchi, 1994), Eurydema rugosa (Motschulsky, 1861) (Numata \& Yamamoto, 1990; Ikeda-Kikue \& Numata, 1992), and Graphosoma lineatum (Breddin, 1896) (Nakamura et al., 1996).

\section{Length of pronotum shoulder (spine) and body coloration}

Adult E. heros showed significantly greater pronotum spine with a $14 \mathrm{~h}$ photophase than bugs reared with photophases of $10 \mathrm{~h}$ or $12 \mathrm{~h}$ (Table $1)$. These differences occurred for both females and males at the three different ages, i.e., 10, 20, and 30-day old adults. Considering the bugs reared at $10 \mathrm{~h}$ and $12 \mathrm{~h}$ of light, the length of the pronotum spine tended to be greater for bugs at $12 \mathrm{~h}$ light, except for males at day 30, when this difference was significant.

When considering the age of adult E. heros, some differences were observed with regard to the length of the pronotum spine. Females of 30 days showed spines significantly longer in photophase $10 \mathrm{~h}$ and $12 \mathrm{~h}$, than those reared in photophase $14 \mathrm{~h}$ (Table 1).

Older males also tended to have longer pronotum spines than younger ones at all photophases, but these differences were not significant. Clearly, additional studies are needed to elucidate this point.

These results on the length of the pronotum spine of E. heros being greater in longer photophase are in agreement with previous studies reported by Kishino \& Alves (1994). McPherson (1974) with Euschistus tristigmus (Say, 1831), and Albuquerque (1989) with Oebalus poecilus (Dallas, 1851), which found summer bugs showing longer spines than winter bugs.

TABLE 1

Lenght of pronotum spines ( $\mathrm{mm}$ ) of females and of males $E$. heros in the laboratory at different ages $(n=20)($ mean $\pm S E M)$.

\begin{tabular}{|c|c|c|c|}
\hline \multirow{2}{*}{ Sex/Age } & \multicolumn{3}{|c|}{ Photophase $^{1}$} \\
\hline & $10 \mathrm{~h}$ & $12 \mathrm{~h}$ & $14 \mathrm{~h}$ \\
\hline \multicolumn{4}{|l|}{ Females } \\
\hline 10 days & $2.59 \pm 0.03 \mathrm{bB}$ & $2.60 \pm 0.04 \mathrm{bB}$ & $2.96 \pm 0.03 \mathrm{aA}$ \\
\hline 20 days & $2.59 \pm 0.04 \mathrm{bB}$ & $2.57 \pm 0.04 \mathrm{bB}$ & $3.00 \pm 0.04 \mathrm{aA}$ \\
\hline 30 days & $2.70 \pm 0.04 \mathrm{aB}$ & $2.70 \pm 0.04 \mathrm{aB}$ & $2.98 \pm 0.04 \mathrm{aA}$ \\
\hline \multicolumn{4}{|l|}{ Males } \\
\hline 10 days & $2.53 \pm 0.02 \mathrm{aB}$ & $2.60 \pm 0.04 \mathrm{aB}$ & $2.79 \pm 0.03 \mathrm{abA}$ \\
\hline 20 days & $2.52 \pm 0.04 \mathrm{aB}$ & $2.55 \pm 0.03 \mathrm{aB}$ & $2.74 \pm 0.03 \mathrm{bA}$ \\
\hline 30 days & $2.54 \pm 0.03 \mathrm{aC}$ & $2.64 \pm 0.04 \mathrm{aB}$ & $2.86 \pm 0.02 \mathrm{aA}$ \\
\hline
\end{tabular}

${ }^{1}$ Means followed by the same lower case letter (in the column) or by the same upper case letter (in the line) do not differ significantly using Duncan's multiple range test $(\mathrm{p} \leq 0.05)$. 
Body color of adult E. heros was variable and two typical colors were observed: dark brown and reddish brown.

At photophases $10 \mathrm{~h}$ and $12 \mathrm{~h}$, no significant differences were observed considering the percentage of bugs with the two distinct colors. However, at the longest photophase $(14 \mathrm{~h})$ a significantly greater number of bugs showed dark brown body color $(65.0 \%)$ than reddish brown $(35.0 \%)$ (Table $2)$. Despite this last difference, body color was considered an unreliable parameter to indicate diapause incidence at shorter photophases. Panizzi \& Niva (1994) stated that during winter, the majority of the bugs were found to be dark brown in the field, which we did not find to be true. This probably occurred because of the small number of bugs examined and because body color is an unreliable trait, as mentioned. For other species of pentatomids such as $N$. viridula (Harris et al., 1984) and O. poecilus (Albuquerque, 1989) body color is considered a more reliable parameter indicating adult diapause, compared to E. heros.

Seasonal dimorphism is very important, and knowledge of its effect among species may prevent taxonomic mistakes with descriptions of new species or subspecies. This occurred with E. tristigmus specimens collected during spring/fall which were identified as E. t. tristigmus, and those collected during summer and identified as E. t. pyrrhocerus (Herrich-Schaeffer, 1842) (McPherson, 1974). A similar mistake occurred with Oebalus grisescens (Sailer, 1944), a hibernating morph of Oebalus ypsilongriseus (De Geer, 1773) (Del Vecchio et al., 1994).

TABLE 2

Color of adult $E$. heros reared in the laboratory at different photophases and recorded at day 20 of adult life $(n=60)$.

\begin{tabular}{|c|c|c|}
\hline \multirow{2}{*}{ Photophase } & \multicolumn{2}{|c|}{ Body color (\%) } \\
\cline { 2 - 3 } & Dark brown & Reddish brown \\
\hline $10 \mathrm{~h}$ & $50.0 \mathrm{~A}$ & $48.0 \mathrm{~A}$ \\
$12 \mathrm{~h}$ & $40.0 \mathrm{~A}$ & $58.0 \mathrm{~A}$ \\
$14 \mathrm{~h}$ & $65.0 \mathrm{~A}$ & $35.0 \mathrm{~B}$ \\
\hline
\end{tabular}

${ }^{1}$ Data followed by the same letter in the line do not differ significantly using $\chi^{2}$ test $\left(10 \mathrm{~h} \chi_{\text {calc }}^{2}=0.03 ; 12 \mathrm{~h} \chi_{\text {calc }}^{2}=1.07\right.$; $\left.14 \mathrm{~h} \chi_{\text {calc }}^{2}=3.84\right)$.

\section{Reproductive performance}

Females E. heros showed a much greater reproductive performance at $14 \mathrm{~h}$ photophase than females at shorter photophases. At the longest photophase, nearly $70 \%$ of the females reproduced, while at $12 \mathrm{~h}$ of light, no females reproduced; with $10 \mathrm{~h}$ of light, ca. $27 \%$ of females laid eggs, but these did not hatch (Table 3 ).

For those females that laid eggs at $10 \mathrm{~h}$ light, the pre-oviposition period was significantly longer, and fecundity (number of egg masses and eggs/ female) was significantly reduced, compared to females at $14 \mathrm{~h}$ of light.

With other pentatomids such as $N$. viridula, no difference in reproductive parameters was observed among bugs reared at $10 \mathrm{~h}$ and $14 \mathrm{~h}$ of light
(Ali \& Ewiess, 1977). However, it is known that $N$. viridula, which is a cosmopolitan species, is much more adapted to lower temperatures than the neotropical stink bug E. heros (Cividanes \& Parra, 1994). For another pentatomid, Dolycoris baccarum (L., 1758), Hodek \& Hodková (1993) reported greater fecundity and shorter pre-oviposition period for bugs reared at longer photophase, than those reared at shorter photophase.

\section{Feeding activity}

Feeding activity, indicated by the number of flanges (stylet sheaths) recorded on soybean pods, increased with the length of the photophase period, and decreased, or tended to, with insect age (Table 4). 
For instance, during the lst week of adult life, the mean number of flanges laid on a soybean pod during $24 \mathrm{~h}$ by an E. heros pair was 28.1 at $14 \mathrm{~h}$ photophase; this value decreased to 21.2 at $12 \mathrm{~h}$ photophase, and to 9.1 at $10 \mathrm{~h}$ photophase.

After 6 weeks, these values were 13.7, 1.9, and 1.8 , respectively (Table 4 ), results supporting previous reports on the low feeding activity of $E$. heros during periods of partial diapause, with accumulation of body lipid reserves (Panizzi \& Hirose, 1995). The accumulation of fat bodies is an indication of diapause (Tauber \& Tauber, 1970; Kotaki \& Yagi, 1989).
The decrease in the feeding activity with age, particularly from the $1^{\text {st }}$ to the $2^{\text {nd }}$ week, is known to occur among hemipterans. For example, $N$. viridula adults will show the peak of feeding activity at day 4 of adult life, decreasing during the $2^{\text {nd }}$ week and levelling off thereafter (Panizzi, 1995).

In conclusion, these results demonstrate that photophase is a key factor governing the biology of the neotropical brown stink bug, E. heros, with shorter photophases with decreased or no reproduction and feeding activity. Photophase is also the driving factor determining the seasonal morphs observed in this species of pentatomid.

TABLE 3

Reproductive performance of females $E$. heros feeding on immature fruits of soybean, in the laboratory at different photophases (number of females in parentheses) (mean $\pm \mathrm{SEM}$ ).

\begin{tabular}{|c|c|c|c|c|c|}
\hline \multirow{2}{*}{ Photophase $^{2}$} & \multirow{2}{*}{$\begin{array}{c}\text { Females } \\
\text { ovipositing } \\
(\%)\end{array}$} & \multirow{2}{*}{$\begin{array}{c}\text { Pre-ovipos. } \\
\text { period } \\
\text { (days) }^{1}\end{array}$} & \multicolumn{2}{|c|}{ Number/female ${ }^{1}$} & \multirow{2}{*}{$\begin{array}{c}\text { Egg hatchability } \\
(\%)\end{array}$} \\
\hline & & & Egg masses & Eggs & \\
\hline $10 \mathrm{~h}$ & $\begin{array}{l}26.7 \\
(4)\end{array}$ & $30.7 \pm 2.29 \mathrm{a}$ & $1.7 \pm 0.25 b$ & $7.0 \pm 1.87 \mathrm{~b}$ & 0.0 \\
\hline $14 \mathrm{~h}$ & $\begin{array}{l}68.7 \\
(11)\end{array}$ & $24.5 \pm 2.59 b$ & $9.6 \pm 0.79 \mathrm{a}$ & $27.3 \pm 7.08 \mathrm{a}$ & $83.1 \pm 7.65$ \\
\hline
\end{tabular}

${ }^{1}$ Means followed by the same letter in each column do not differ significantly using Student's $t$ test ( $\left.\mathrm{p} \leq 0.05\right)$. ${ }^{2}$ No females reproduced at under $12 \mathrm{~h}$ photophase.

TABLE 4

Number of stylet sheaths deposited on a soybean pod by a pair of $E$. heros adults during $24 \mathrm{~h}$ in the laboratory at different photophases $(n=15)($ mean \pm SEM $)$.

\begin{tabular}{|c|c|c|c|}
\hline \multirow{2}{*}{ Week } & \multicolumn{3}{|c|}{ Photophase $^{\mathbf{1}}$} \\
\cline { 2 - 4 } & $\mathbf{1 0 ~ h}$ & $\mathbf{1 2} \mathbf{~ h}$ & $\mathbf{1 4 ~ h}$ \\
\hline 1 & $9.1 \pm 1.84 \mathrm{aB}$ & $21.2 \pm 3.68 \mathrm{aA}$ & $28.1 \pm 3.23 \mathrm{aA}$ \\
\hline 2 & $3.1 \pm 1.18 \mathrm{bB}$ & $4.0 \pm 1.07 \mathrm{bB}$ & $22.8 \pm 3.14 \mathrm{aA}$ \\
\hline 3 & $1.5 \pm 0.05 \mathrm{bB}$ & $1.5 \pm 0.67 \mathrm{bB}$ & $7.1 \pm 1.38 \mathrm{bA}$ \\
\hline 4 & $2.7 \pm 0.99 \mathrm{bB}$ & $3.2 \pm 0.82 \mathrm{bB}$ & $12.0 \pm 2.92 \mathrm{bA}$ \\
\hline 5 & $2.7 \pm 1.06 \mathrm{bB}$ & $2.7 \pm 0.44 \mathrm{bB}$ & $12.8 \pm 2.30 \mathrm{bA}$ \\
\hline 6 & $1.8 \pm 0.47 \mathrm{bB}$ & $1.9 \pm 1.12 \mathrm{bB}$ & $13.7 \pm 3.08 \mathrm{bA}$ \\
\hline
\end{tabular}

${ }^{1}$ Means followed by the same lower letter (in the column) or by the same upper letter (in the line) do not differ significantly using Duncan's multiple range test $(\mathrm{p} \leq 0.05)$. 
Acknowledgments - We thank Gilberto S. Albuquerque (UENF), Amarildo Pasini (UEL), Beatriz S. Corrêa-Ferreira and José B. França Neto (Embrapa Soja), for critical review of the manuscript. This is article number 031/2000 of Embrapa Soja, published with permission of the Head of Research and Development.

\section{REFERENCES}

ALBUQUERQUE, G. S., 1989, Ecologia de populações, biologia e estratégias da história de vida de Oebalus poecilus (Dallas, 1851) (Hemiptera: Pentatomidae). Dissertação de Mestrado, UFRGS, Porto Alegre, 309p.

ALI, M. \& EWIESS, M. A., 1977, Photoperiodic and temperature effects on rate of development and diapause in the green stink bug, Nezara viridula L. (Heteroptera: Pentatomidae). Z. Ang. Ent., 84: 256-264.

BANERJEE, T. C. \& CHATTERJEE, M., 1985, Seasonal changes in feeding, fat body and ovarian conditions of Nezara viridula L. (Heteroptera: Pentatomidae). Insect. Sci. Applic., 6: 633-635.

CIVIDANES, F. J. \& PARRA, J. R. P., 1994, Zoneamento ecológico de Nezara viridula (L.), Piezodorus guildinii (West.) e Euschistus heros (Fabr.) (Heteroptera: Pentatomidae) em quatro estados produtores de soja do Brasil. An. Soc. Entomol. Brasil, 23: 219-226.

DEL VECCHIO, M. C., GRAZIA, J. \& ALBUQUERQUE, G. S., 1994, Dimorfismo sazonal em Oebalus ypsilongriseus (De Geer, 1773) (Hemiptera, Pentatomidae) e uma nova sinonímia. Rev. Bras. Ent., 38: 101-108.

DENLINGER, D. L., 1986, Dormancy in tropical insects. Annu. Rev. Entomol., 31: 239-264.

HARRIS, V. E., TODD, J. W. \& MULLINIX, B. G., 1984, Color change as an indicator of adult diapause in the southern green stink bug Nezara viridula. J. Agric. Entomol., 1: $82-91$.

HIGUCHI, H., 1994, Photoperiodic induction of diapause hibernation and voltinism in Piezodorus hybneri (Heteroptera: Pentatomidae). Appl. Entomol. Zool., 29: 585-592.

HODEK, I. \& HODKOVÁ, M., 1993, Role of temperature and photoperiod in diapause regulation in Czech populations of Dolycoris baccarum (Heteroptera: Pentatomidae). Eur. J. Entomol., 90: 95-98.

IKEDA-KIKUE, K. \& NUMATA, H., 1992, Effects of diet, photoperiod and temperature on the postdiapause reproduction in the cabbage bug, Eurydema rugosa. Entomol. Exp. Appl., 64: 31-36

KIRITANI, K., 1963, The change in reproductive system of the southern green stink bug, Nezara viridula and its application to forecasting of the seasonal history. Jap. J. Appl. Ent. Zool., 7: 327-336.

KISHINO, K. \& ALVES, R. T., 1994, Pragas que atacam a soja na região dos Cerrados. Rel. Téc. Proj. Nipo-Brasileiro Coop. Pesq. Agr., 1: 89-115.

KOSHIYAMA, Y., FUJISAKI, K. \& NAKASUJI, F., 1994, Mating and diapause in hibernating adults of Menida scotti Puton (Heteroptera: Pentatomidae). Res. Pop. Ecol., 36: 87-92.
KOTAKI, T. \& YAGI, S., 1989, Hormonal control of adult diapause in the brown-winged green bug, Plautia stali Scott (Heteroptera: Pentatomidae). Appl. Entomol. Zool., 24: 42-51.

McPHERSON, J. E., 1974, Photoperiod effects in a southern Illinois population of the Euschistus tristigmus complex (Hemiptera: Pentatomidae). Ann. Entomol. Soc. Am., 67: 943-952.

McPHERSON, J. E., 1975, Effects of developmental photoperiod on adult morphology in Euschistus tristigmus (Say) (Hemiptera: Pentatomidae). Ann. Entomol. Soc. Am., 68: 1107-1110.

McPHERSON, J. E., 1977, Effects of developmental photoperiod on adult color and pubescence in Thyanta calceata (Hemiptera: Pentatomidae) with information on ability of adults to change color. Ann. Entomol. Soc. Am., 70: 373-376.

MOURÃO, A. P. M. \& PANIZZI, A. R., 2000a, Diapausa e diferentes formas sazonais em Euschistus heros (Fabr.) (Hemiptera: Pentatomidae) no Norte do Paraná. An. Soc. Entomol. Brasil, 29: 205-218.

MOURÃO, A. P. M. \& PANIZZI, A. R., 2000b, Estágios ninfais fotossensíveis à indução da diapausa em Euschistus heros (Fabr.) (Hemiptera: Pentatomidae). An. Soc. Entomol. Brasil, 29: 219-225.

NAKAMURA, K., HODEK, I. \& HODKOVÁ, M., 1996, Recurrent photoperiodic response in Graphosoma lineatum (Heteroptera: Pentatomidae). Eur. J. Entomol., 93: 519-523.

NUMATA, H. \& YAMAMOTO, K., 1990, Feeding on seeds induces diapause in the cabbage bug, Eurydema rugosa. Entomologia, 57: 281-284.

PANIZZI, A. R., 1995, Feeding frequency, duration and preference of the southern green stink bug (Heteroptera: Pentatomidae) as affected by stage of development, age, and physiological condition. An. Soc. Entomol. Brasil, 24: 437-444.

PANIZZI, A. R., CORRÊA, B. S., GAZZONI, D. L., OLIVEIRA, E. B., NEWMAN, G. G. \& TURNIPSEED, S. G., 1977, Insetos da soja no Brasil, Centro Nacional de Pesquisa de Soja. Bol. Téc., 1: 1-20.

PANIZZI, A. R. \& HIROSE, E., 1995, Seasonal body weight, lipid content, and impact of starvation and water stress on adult survivorship and longevity of Nezara viridula and Euschistus heros. Entomol. Exp. Appl., 76: 247-253.

PANIZZI, A. R. \& NIVA, C. C., 1994, Overwintering strategy of the brown stink bug in northern Paraná. Pesq. Agropec. Bras., 29: 509-511.

SAS INSTITUTE, 1981, SAS for linear models. A guide to the ANOVA and GLM procedures. SAS Institute, Cary, N.C.

SOLBRECK, C., 1972, Sexual cycle, and changes in feeding activity and fat size in relation to migration in Lygaeus equestris (L.) (Het, Lygaeidae). Entomol. Scand., 3: 267274.

TAUBER, M. J. \& TAUBER, C. A., 1970, Photoperiodic induction and termination of diapause in an insect: response to changing day lengths. Science, 167: 170.

TAUBER, M. J., TAUBER, C. A. \& MASAKI, S., 1986, Seasonal adaptations of insects. New York, Oxford University Press, 411p. 